\title{
Pulmonary Arterial Hypertension in a Patient with Connective Tissue Disease and ALCAPA Syndrome
}

\section{Konnektif Doku Hastalığı ve ALCAPA Sendromu olan Bir Hastada Pulmoner Arteriyal Hipertansiyon}

Wang Kin Wong', Wan-Jing $\mathrm{Ho}^{2}$, Jaw-Ji Chü, Shue-Fen Luo ${ }^{4}$

\section{Abstract}

A 43-year-old female with mixed connective tissue disease was incidentally discovered to be an adult survivor of an anomalous left coronary artery originating from the pulmonary artery during a work-up for her pulmonary hypertension. We describe here the management strategy of severe pulmonary hypertension prior to and after the surgical correction of the congenital anomaly.

Key words: Pulmonary hypertension, pulmonary arterial hypertension, anomalous left coronary artery originating from the pulmonary artery, ALCAPA, connective tissue disease.

\section{Özet}

Mikst konnektif doku hastalığı olan 43 yaşındaki kadında, pulmoner arteriyel hipertansiyon araştırmaları sırasında, yaşayan bir yetişkinde, pulmoner arterden orijin alan sol koroner arter anomalisi saptandı. Konjenital anomalinin cerrahi tedavisi öncesi ve sonrası, ciddi pulmoner hipertansiyon yönetim stratejisini açıklıyoruz.

Anahtar Sözcükler: Pulmoner arteriyal hipertansiyon, pulmoner hipertansiyon, pulmoner arterden kaynaklanan sol koroner arter anomalisi, ALCAPA, konnektif doku hastalığı.
'School of Medicine, Chang Gung University, Chang Gung Memorial Hospital, Tao-Yuan, Taiwan

2Department of Cardiology, Chang Gung Memorial Hospital,

Chang Gung University, Tao-Yuan, Taiwan

${ }^{3}$ Department of Cardiothoracic and Vascular Surgery, Chang

Gung Memorial Hospital, Chang Gung University, Tao-Yuan,

Taiwan

${ }^{4}$ Department of Rheumatology, Allergy and Immunology, Chang

Gung Memorial Hospital, Chang Gung University, Tao-Yuan, Taiwan
'Chang Gung Üniversitesi Tıp Fakültesi, Chang Gung Memorial Hastanesi, Tao-Yuan, Tayvan

${ }^{2}$ Chang Gung Üniversitesi, Chang Gung Memorial Hastanesi, Kardiyoloji Bölümü, Tao-Yuan, Tayvan

${ }^{3}$ Chang Gung Üniversitesi, Chang Gung Memorial Hastanesi, Kardiotorasik ve Vasküler Cerrahi Bölümü, Tao-Yuan, Tayvan ${ }^{4}$ Chang Gung Üniversitesi, Chang Gung Memorial Hastanesi, Romatoloji, Allerii ve İmmünoloji Bölümü, Tao-Yuan, Tayvan

Submitted (Başvuru tarihi): 20.12.2020 Accepted (Kabul tarihi): 06.01.2021

Correspondence (iletişim): Wan-Jing Ho, Department of Cardiology, Chang Gung Memorial Hospital, Chang Gung University, Tao-Yuan, Taiwan

e-mail: auditory@cgmh.org.tw 
Anomalous left coronary artery originating from the pulmonary artery (ALCAPA) is a rare congenital heart disease (CHD) that can be classified into infant and adult types (1). Most of those with the infant type die from heart failure during infancy secondary to myocardial ischemia. Patients with the adult type survive due to collateral development between the left and right coronary arteries, although they may be susceptible to chronic myocardial ischemia, pulmonary hypertension $(\mathrm{PH})$ and sudden cardiac death. Pulmonary hypertension $(\mathrm{PH})$ is classified into five subgroups: Pulmonary arterial hypertension (PAH), $\mathrm{PH}$ due to left heart disease, $\mathrm{PH}$ due to chronic lung disease (CLD) and/or hypoxia, PH due to pulmonary artery obstruction, and $\mathrm{PH}$ with an unclear and/or multifactorial mechanism. PAH fulfills the hemodynamic criteria of an $m P A P>20 \mathrm{mmHg}$, PAWP $\leq 15 \mathrm{mmHg}$, and PVR $\geq 3 \mathrm{WU}$ (2). PAH may be idiopathic or secondary to other diseases such as connective tissue disease (CTD), CHD, chronic liver disease, HIV infection, or schistosomiasis.

\section{CASE}

We report here on the case of a 43-year-old woman with a 3-4-month history of progressive dyspnea on exertion, with a WHO function class (FC) of III. A physical examination revealed a regular pulse of 92 beats $/ \mathrm{min}$, blood pressure of 136/93 $\mathrm{mm} \mathrm{Hg}$ and respiratory rate of 16 breaths/min. Cardiac auscultation revealed an accentuation of P2 without murmur. Edema was absent in both legs.

The patient had long-term mixed connective tissue disease (CTD), including systemic sclerosis and systemic lupus erythematous. Her surgical and family history was unremarkable.

Serologic studies showed the level of C3 and C4 to be within normal limits and the anti-dsDNA antibody was negative. The serum brain natriuretic peptide (BNP) level was $43.5 \mathrm{pg} / \mathrm{ml}$. To assess whether the pulmonary hypertension $(\mathrm{PH})$ was related to $C L D$, a pulmonary function test (PFT) was carried out, revealing a forced expiratory volume in $1 \mathrm{~s}$ and a forced vital capacity (FVC) ratio of $80 \%$, a FVC of $71 \%$, a diffusing capacity of the lung for carbon monoxide (DLCO) of 54\%, and a DLCO/alveolar volume ratio of $85 \%$. The 6 -min walk distance (6MWD) was $559 \mathrm{~m}$ and chest radiography (Figure 1a) revealed moderate cardiomegaly. A high-resolution computed tomography (HRCT) of the chest revealed interstitial lung disease (ILD) limited to the lower lung fields (Figure lb). Echocardiography revealed severe $\mathrm{PH}$, a hypertrophic right ventricle, a dilated main pulmonary artery (MPA), normal left ventricular systolic function (ejection fraction $=79 \%$ ) and a large amount of pericardial effusion. A lung perfusion scan revealed a low probability of pulmonary emboli. To confirm the diagnosis of pulmonary arterial hypertension related to CTD (CTD-PAH), cardiac catheterization was performed and the hemodynamic data obtained were as follows: right atrial pressure (RAP), $8 \mathrm{mmHg}$; mean pulmonary artery pressure (mPAP), 57 $\mathrm{mmHg}$; pulmonary artery wedge pressure (PAWP), 15 $\mathrm{mmHg}$; cardiac output (CO), $3.4 \mathrm{l} / \mathrm{min}$; cardiac index (Cl), $2.4 \mathrm{l} / \mathrm{min} \cdot \mathrm{m}^{2}$; and pulmonary vascular resistance (PVR), 12 WU. A 7\% step-up in oxygen saturation was observed in the MPA with a pulmonary-systemic flow ratio (Qp/Qs) of 1.3. An anomalous left coronary artery originating from the pulmonary artery (ALCAPA) was detected during a right coronary angiography (Figure $2 a$ and $b$, Video 1 and $2 \square$ ), and a 3D-CT angiography was performed to reveal the ALCAPA and adjacent structures (Figure $3 a$ and $b$ ).
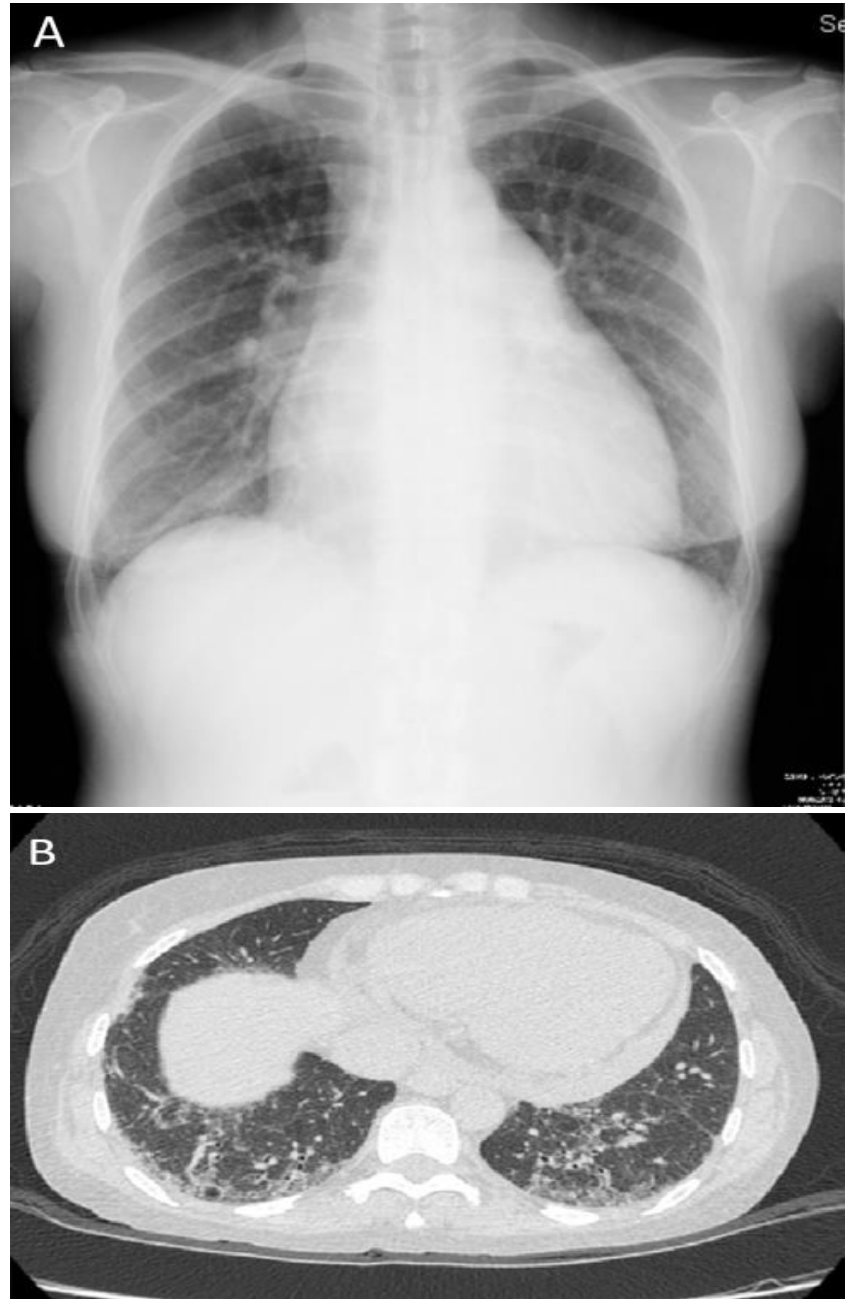

Figure 1a and b: Frontal chest x-ray showing moderate cardiomegaly (a); an axial image from high-resolution computed tomography (CT) demonstrating interstitial lung fibrosis (b) 

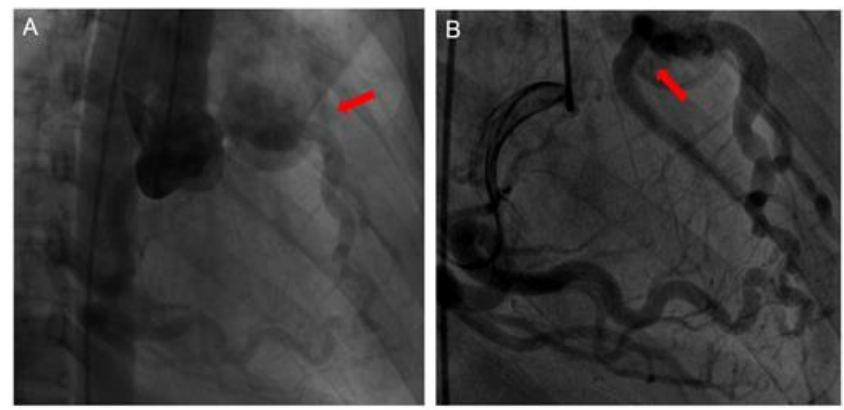

Figure $2 a$ and $b$ : Aortogram showing the pulmonary artery and the anomalous left coronary artery originating from the pulmonary artery (ALCAPA) (red arrow) (a); a selective right coronary angiogram showing the ALCAPA (red arrow) (b)
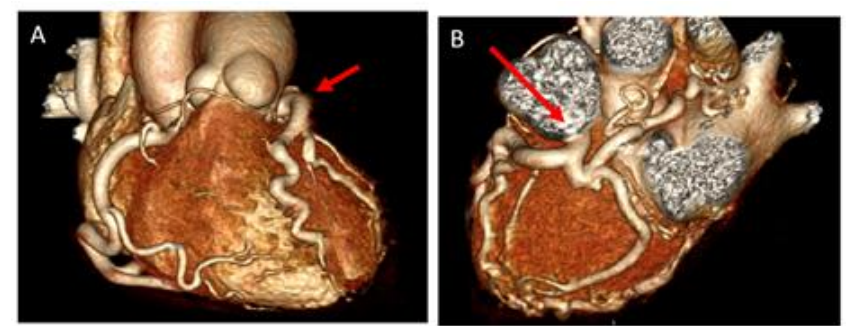

Figure 3a and b: A 3-dimensional reconstruction CT angiogram of the anterior (a) and lateral view, respectively, showing an anomalous coronary artery originating from the pulmonary artery (ALCAPA) (red arrow) (b)

\section{DISCUSSION}

This case highlights the difficulty in determining the cause and subsequent management of $\mathrm{PH}$ owing to the coexistence of ALCAPA, CTD and ILD. Due to the presence of a large pericardial effusion, $\mathrm{PH}$ related to CTD activity was the first consideration, although serologic studies disproved the flare up of CTD. Cardiac catheterization was performed, as $\mathrm{PAH}$ was the most likely diagnosis, although ALCAPA with a significant systemic to pulmonary shunt was discovered incidentally. Though ILD was present, the PFT showed only mild restriction (FVC >70\%), and a chest HRCT revealed limited ILD. As the CLD was assessed to be physiologically and morphologically mild, CLD-PH was less likely, and so should be treated as PAH (3). Following multidisciplinary discussions, a surgical correction for the CHD was performed, based on the presumption that PAH may be related to CHD and CTD, although progressive dyspnea re-emerged after the procedure. An echocardiographic study followed by RHC supported the confirmation of the $\mathrm{PAH}$ diagnosis. PDE-5i is effective both for CTD-PAH and persistent PAH after CHD correction (4). After undergoing therapy, the patient's exercise capacity improved and their serum BNP level decreased.

\section{CONCLUSION}

The identification of the main cause of PAH was challenging in this patient due to the co-existence of ALCAPA, CTD and ILD. Managing this complex condition requires multidisciplinary care.

\section{CONFLICTS OF INTEREST}

None declared.

\section{AUTHOR CONTRIBUTIONS}

Concept - W.K.W., W.J.H., J.J.C., S.F.L.; Planning and Design - W.K.W., W.J.H., J.J.C., S.F.L.; Supervision W.K.W., W.J.H., J.J.C., S.F.L.; Funding -; Materials S.F.L., J.J.C.; Data Collection and/or Processing - W.J.H., S.F.L., J.J.C.; Analysis and/or Interpretation - W.K.H., W.J.W.; Literature Review - W.K.H., W.J.W.; Writing W.K.H., W.J.W.; Critical Review - W.K.W., W.J.H., J.J.C., S.F.L.

\section{YAZAR KATKILARI}

Fikir - W.K.W., W.J.H., J.J.C., S.F.L.; Tasarım ve Dizayn W.K.W., W.J.H., J.J.C., S.F.L.; Denetleme - W.K.W., W.J.H., J.J.C., S.F.L.; Kaynaklar -; Malzemeler - S.F.L., J.J.C.; Veri Toplama ve/veya İşleme - W.J.H., S.F.L., J.J.C.; Analiz ve/veya Yorum - W.K.H., W.J.W.; Literatür Taraması - W.K.H., W.J.W.; Yazıyı Yazan - W.K.H., W.J.W.; Eleştirel İnceleme - W.K.W., W.J.H., J.J.C., S.F.L.

\section{REFERENCES}

1. Mori K, Anai H, Wada T, Shuto T, Miyamoto S. Reconstruction of anomalous left coronary artery from pulmonary artery in an adult patient: a case report. J Cardiothorac Surg 2019; 14:40. [CrossRef]

2. Simonneau G, Montani D, Celermajer DS, Denton $C P$, Gatzoulis MA, Krowka M, Williams PG, Souza R. Haemodynamic definitions and updated clinical classification of pulmonary hypertension. Eur Respir J 2019; 53:1801913. [CrossRef]

3. Nathan SD, Barbera JA, Gaine SP, Harari S, Martinez FJ, Olschewski $\mathrm{H}$, et al. Pulmonary hypertension in chronic lung disease and hypoxia. Eur Respir J 2019; 53:1801914. [CrossRef]

4. D'Alto M, Diller GP. Pulmonary hypertension in adults with congenital heart disease and Eisenmenger syndrome: current advanced management strategies. Heart. 2014; 100:1322-8. [CrossRef] 